\title{
Seismic Vulnerability Mapping to Support Spatial Plans in Lhokseumawe City Area
}

\author{
Deassy Siska $^{\# 1}$, Herman Fithra ${ }^{\# 2}$, Nova Purnama Lisa ${ }^{\# 3}$, Nandi Haerudin ${ }^{*}$, Muhammad Farid ${ }^{+}$ \\ ${ }^{\#}$ Engineering Faculty, Universitas Malikussaleh, Bukit Indah Village, Lhokseumawe, 24352, Indonesia \\ E-mail: ${ }^{\# 1}$ deassy@unimal.ac.id: ${ }^{\# 2}$ fithra@unimal.ac.id; ${ }^{\# 3}$ novapurnamalisa@gmail.com \\ *Science Faculty, Geophysics Department, Universitas Lampung, Bandar Lampung City, Lampung 35141, Indonesia. \\ E-mail: nandithea@yahoo.com \\ ${ }^{+}$Science Faculty, Physic Department, Universitas Bengkulu, Muara Bangka Hulu, Bengkulu City, Bengkulu 38371, Indonesia. \\ E-mail: mfarid@unib.ac.id
}

\begin{abstract}
Earthquake loads that work on building structures can be determined by doing calculations ground motion on the surface. The amplitude from ground vibration is correlated with earthquake energy and ground solidity (compaction). The ductile ground will amplify the earthquake energy so that it produces strong vibration to the ground and building on the surface. This study will provide a mapping of areas susceptible to seismic vibrations to produce sustainable Lhokseumawe City spatial management plan policies as supporting literature in City development planning. The results of the study are expected to be disseminated to the community and as input for the Regional Government in planning the development of the city of Lhokseumawe. This research contributed to the development of cross-sectoral science in the assessment of the danger of micro seismic earthquakes. The results of the study were mapping areas that were susceptible to seismic vibration as a basis for spatial planning for the city of Lhokseumawe. The essential linkages in the field of science are on geophysics and architecture. The needs of the study carried out micro seismic data collection in the Lhokseumawe area using micro seismic equipment. The results of this study are the existence of areas that are very susceptible to seismic, namely Ujong Blang and Banda Sakti villages with seismic vulnerability index values (Kg) ranging from $0 \mathrm{~cm} / \mathrm{s} 2-30542.32$ $\mathrm{cm} / \mathrm{s} 2$. The highest value is located at Ujong Blang Village start from point A10, which is $10397.1 \mathrm{~cm} / \mathrm{s} 2$. This is finally related to the full damage to buildings in Lhokseumawe City during the 2004 earthquake.
\end{abstract}

Keywords — seismic vulnerability index; HVSR; spectrum; earth quake.

\section{INTRODUCTION}

The position of Nanggroe Aceh Darussalam is flanked by subduction zones (subduction) between the IndianAustralian and Euro-Asian plates in the west and the Sumatra Fault zone in the east. The description of the geological conditions shows that the City of Lhokseumawe was formed by Alluvium Young rocks, Idi Formation, Julurayeu formation, and Seureula formation. Distribution of rocks Alluvium The forms of coastal sediment and fluviatile are in the northern part of the city and south of Lhokseumawe. The distribution of the Idi Formation in the form of gravel, sand, limestone, and clay is in the western part of the area of Muara Satu and Muara Dua Subdistricts, and in the east part of Muara Dua and Blang Mangat Districts.

The distribution of the Julurayeu formation in the form of tophaceous sandstone sediments, lignite clay, and mudstones is in the western to central areas of Lhokseumawe City, namely parts of Muara Satu District and Muara Dua District. Whereas the distribution of the Seureula Formation is in the form of volcanic sandstones, and the mud rock limestone is in the middle area of the City of Lhokseumawe, which is part of the Muara Satu and Muara Dua Subdistricts as in Figure 1. The amplitude from ground vibration is correlated with earthquake energy and ground solidity (compaction). The ductile ground will amplify the earthquake energy so that it produces energetic vibration to the ground and building on the surface. The vibration characteristic formed is analogous to damped wave with vibration frequency [1]. Vulnerability to shocks is not only felt through earthquakes but also by the presence of small vibrations that cannot be contacted, called micro seismic. The method is used to detect micro-vibrations in the HVSR manner. This method is also used by researchers in this study. in addition to HVSR, the researchers also used the newly proposed Matching Algorithm to detect and analyze micro seismic events that entered the recording by looking at 
vibrations at specific frequencies. This method requires a recording place that is free of noise. the results obtained will be accurate if using conventional micro seismic processing, then the signal is filtered and selected based on a high signal-to-noise $(\mathrm{S} / \mathrm{N})$ ratio and is distributed on the recorded micro seismicity [2].

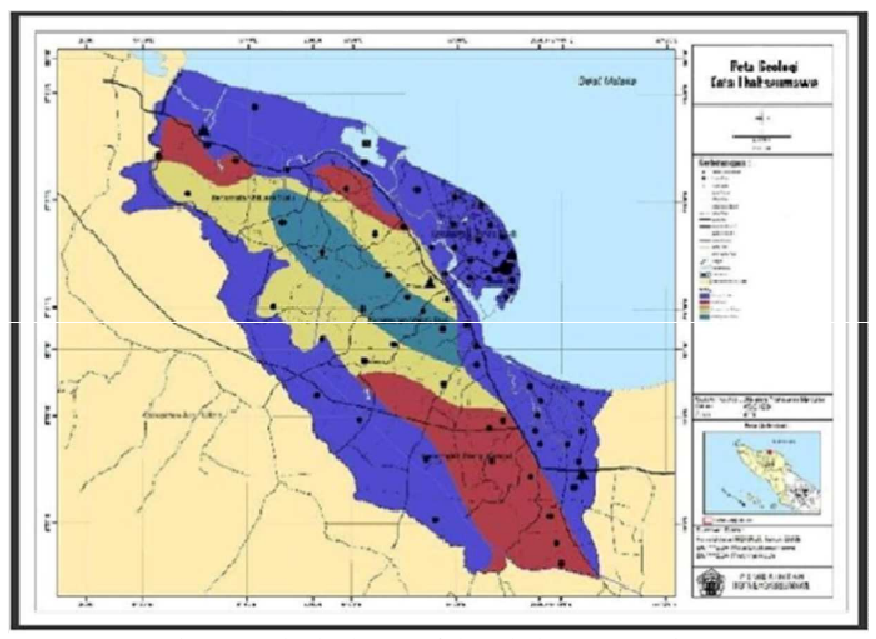

Fig 1. Geological map of the Lhokseumawe City [3]

Earthquake loads that work on building structures can be determined by making calculations ground motion on the surface. Land movement parameters needed for planning of earthquake-resistant infrastructure is maximum ground acceleration (Peak Ground) Acceleration / PGA), earthquake spectra response (seismic) response spectra), and history of acceleration time earthquake (acceleration time history / $\mathrm{TH})$. The size PGA, Response Spectra, and TH can be determined by analyzing the wave propagation earthquake from bedrock to ground level. Movement of earthquake waves from bedrock to the surface is affected by the condition of the soil layer where the earthquake wave propagates [4], [5].

The best way to look for amplification factors is to make observations see how the local geology influences at the time an earthquake occurred - inspection done by observing earthquake waves that are captured on the bedrock and on the surface soil. With recording data of earthquake waves on bedrock and on the surface, it can predict the magnitude of the amplification factor layer sediment at one point of observation. Tools that used to record waves earthquake is a seismometer. To guarantee the accuracy of recording earthquake waves, then the placement of seismometers, in general, carried out at points adjacent to the source of the earthquake. Another approach that can also be done to predict the amplification factor is by conducting microtremor research [6]. Microtremor Research is done by utilizing waves ambient (ambient vibrations) that appear on around the location of the seismometer. Analytical approach to predict the value of the amplification factor Nakamura's introduction was elementary because it ignores the geological conditions at the location observation. In order to get a factor value, Nakamura's amplification introduced one analytical method known as Horizontal to Vertical Spectral Ratio (HVSR). Micro seismic signals that have been successfully recorded by a three-component seismometer will be filtered with a frequency value below $1 \mathrm{~Hz}$. [7]
The recording process of natural and damped ground vibrations is a fundamental principle of micro seismic. When the ground experiences the slightest and slightest vibration, the vibration recording will be sent via waves to the seismometer. [8]. The micro seismic recording process is a technology used by researchers in the field of geophysics to detect the presence of micro-vibrations originating from muffled vibrations from inside the earth. In recent years, many researchers have published research results in the field of microtremor about the use of a micro activity to obtain the values of frequency, wavelength, azimuth, noise, and complexity of ground movement in simple terms. [9]

\section{MATERIALS AND METHOD}

The measured microtremor data is obtained from 3 signals whose components are vertical (Up and Down), horizontal (North-South), and horizontal (East-West) components. After the message is obtained, it can then be analyzed using the HVSR method, and the values of dominant frequency and amplification are obtained. This HVSR method compares the ratio of the spectrum from the microtremor signal to the horizontal component to its vertical component [11].

HVSR is a method of analysis introduced by Nakamura based on his experience of making observations shear wave propagation due to events earthquake. Nakamura and Saito (1983) did seismic wave propagation observations for various geological conditions. the $\mathrm{H} / \mathrm{V}$ spectral ratio was found from the reliable motion records at multiple sites in Japan. On the soft ground, horizontal motion is more significant than vertical movement. On the other hand, on the hard ground, both horizontal and vertical movements are like each other both on the maximum value and waveform [6]. Results Nakamura and Saito's observations (1983) indicates that the ground moves on the surface due to earthquake and ambient consequences vibrations caused by Rayleigh waves (e.g., Fig 2). The basic concept of the HVSR method is the existence similarity between the ratio of horizontal spectra to vertical with wave transfer from bedrock to surface (Nakamura, 1989). Nakamura conveys that the dominant period and value the peak of the spectral ratio $(\mathrm{H} / \mathrm{V})$ has similarity with natural periods and factors amplification of the soil layer, the $\mathrm{H} / \mathrm{V}$ value is obtained from the comparison between the amplitude spectrum Fourier horizontal wave component towards the vertical wave. Measurement of the dominant period of land is carried out by using ambient vibrations with minimizing or reduce tremor vibration caused by human and machine movements or other sources of tremor. By reducing vibration due to human and machine movements, oscillations recorded by seismometers only comes from ground motion. Because of change, humans or machines often occur during the day; then, the ground motion data search process will better if done at night or in places far from activities everyday humans.

Soil amplification factor research in the City Lhokseumawe is done at 10 observation points, which is divided into two lines of observation. Each row consists of 5 points of consideration. Field testing uses the Feedback Short Period Seismometer tool. The inspection of ambient waves is carried out during 30 minutes with a frequency of 
$100 \mathrm{~Hz}$. Using a wavelength of $100 \mathrm{~Hz}$, then every minute will produce 6000 data - Source of vibration taken from the ambient vibrations obtained at around the observation location. The equipment used is GPS, data logger, seismometer, and laptop computers.

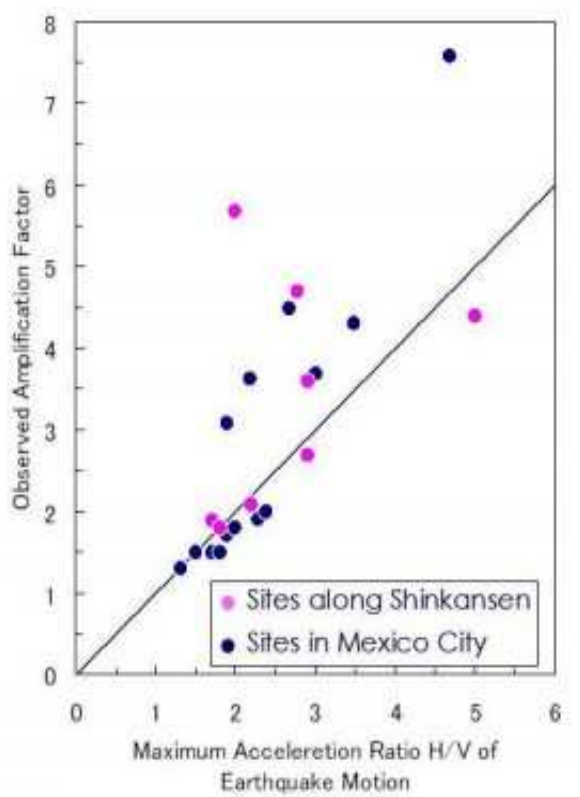

Fig. 2. The Comparison of the value of the amplification factor the results of HVSR analysis and data observations earthquake [6].

In this research, ambient vibrations were obtained from vibrations that arise around the point of the seismometer. Ambient vibration captured on a seismometer captured from vibrations caused by vehicle movement, plant movements as a result of wind blowing, or by using vibration caused by the collision of the hammer above ground level. The wave captured by the seismometer is then recorded by the data logger and displayed on the monitor screen.

Waves used in this research are microtremor, which is ambient vibrations with low amplitude. This wave can be caused by ground motion, wind motion, ocean waves, or vibrations from vehicles. Microtremor observation is easy to do and can be applied to regions with high to low seismicity. Nakamura [6] stated that value the amplification factor of a place can be known from the high peak spectrum of the HVSR curve results microtremor measurements in that place. The dominant value period or dominant frequency obtained from the HVSR curve has a correlation with the thickness of the sediment layer.

Research ambient vibrations with using the HVSR method has also been done by many researchers, such as [12], [13], [14], and [15]. Microtremor signals that are included in the seismometer record have a specific frequency that is different from the earthquake signal. the shape of the signal can be seen in the image below as in Fig. 3

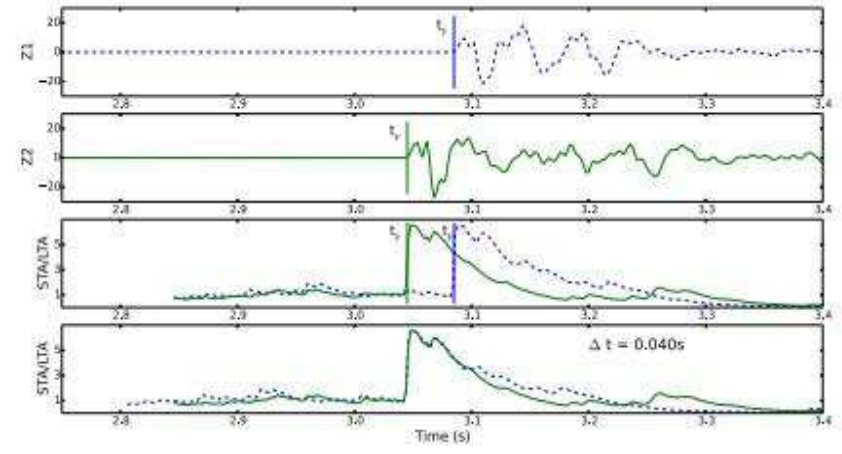

Fig. 3. Three-component seismogram of the two geophones (Z1 and Z2) in the top two panels.

The picture above also shows the STA / LTA function for seismograms, and the bottom panel image serves to illustrate the STA / LTA wave that is shifted for maximum crosscorrelation. The arriving-P stream is selected when the STA / LTA wave function is above the threshold given on the two records for the time difference $t$ which is within the expected time difference for the arrival time on both geophones (0.020.05 seconds) [16]. Signals obtained from recorded data usually take the form of irregular noise [17]; these signals must be filtered first to eliminate noise and get a clear signal (e.g., fig. 4).

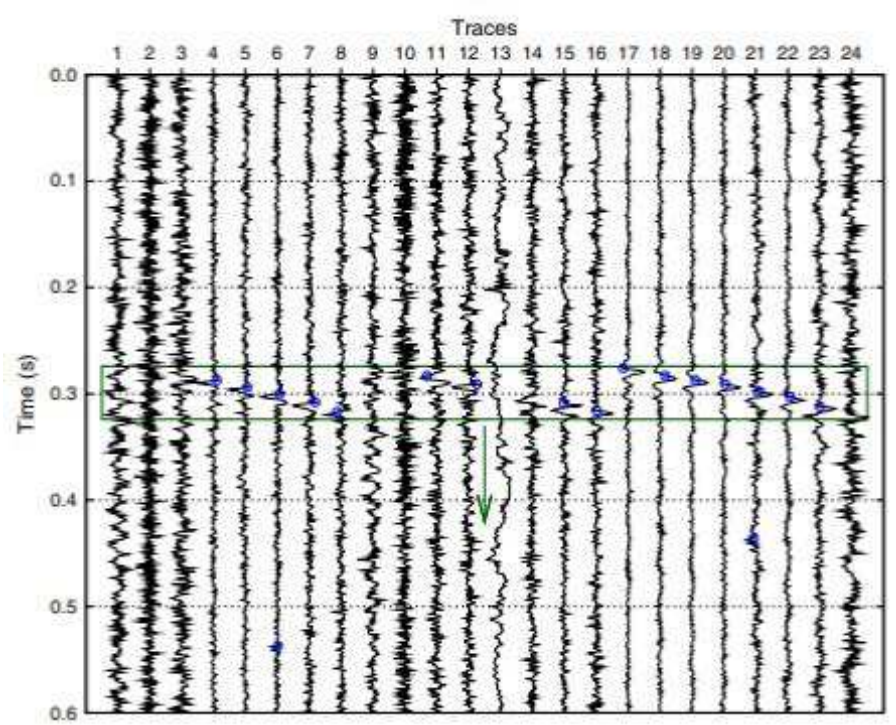

Fig. 4. This picture is a sequence of microtremor signal sequences separated over time windows. if sorted, there will be a very significant difference in signal cutting.

The most appropriate way to do it look for the value of accelerating ground motion on the surface is to use the amplification factor. The amplification factor gives an idea of change (enlargement) of the acceleration of ground motion from bedrock to the surface. Enlargement acceleration of land from bedrock to surface is caused by differences in the speed of movement shear waves (Vs) on bedrock and on soil layer (sediment). Vs. value from bedrock to the surface will shrink. The amount of Vs. getting smaller causes smaller shear modulus (Gs) and damping factor $(()$, so that the land acceleration will increase. 
The higher the amplification factor value, then the higher the acceleration of the ground movement on the surface. The best way to look for amplification factors is to make observations direct influence from the local geology at the time experienced an earthquake event - inspection done by observing earthquake waves that are captured on the bedrock and on the surface soil. With recording data of earthquake waves on bedrock and on the surface, it can predict the magnitude of the amplification factor layer sediment at one point of observation. Tools that used to record waves earthquake is a seismometer. To guarantee the accuracy of recording earthquake waves, then the placement of seismometers carried out at points adjacent to the source of the quake.

\section{RESULT AND DISCUSSION}

Micro zonation is an attempt to evaluate and map or describe the potential for disasters in an area, which is generally caused by strong ground vibrations during an earthquake. These hazards include ground vibration amplification, liquefaction, and potential landslides. Liquidation is the process when the sediment layer loses strength and is more of a thick liquid than reliable. Micro zonation maps are used to describe the potential for natural disasters. If the micro zonation map is combined with information on microtremor data for an area, it can be used to develop various natural disaster management strategies.

The results of micro zonation show that when there is substantial ground vibration, severe damage may occur in areas that have high seismic susceptibility. Information contained in a disaster map of a region cannot be used as a reference for evaluating other areas, because each city has its own disaster map according to the characteristics of the land and its rocks [18].

Based on observations of ambient waves at 10 points using a seismometer, three NS wave direction components will be obtained (north-south), EW (east-west), and V (vertical). The three parts of the ambient wave data then processed using the method HVSR and Geopsy software facilities. Analysis results with the HVSR way will produce a graph

relationship between $\mathrm{H} / \mathrm{V}$ and frequency. Factor Soil amplification is obtained from the $\max \mathrm{H} / \mathrm{V}$ value on the dominant frequency $(\mathrm{Fo})$.

Buildings in Lhokseumawe City include settlements and housing, health facilities, general education, religious education, and worship. Health facilities available in Lhokseumawe City consist of 5 health centers, 12 sub-health centers, 32 village maternity huts, 85 doctor practices, 9 dental practices, and 77 drug stores. Public education facilities in Lhokseumawe City until 2007 consisted of Kindergarten 25 units (private 24 units), Elementary Schools as many as 59 units, Junior high schools' number 15 units. There are 8 religious education units in Madrasah Ibtidaiyah ( 5 countries and 3 private groups), 6 Madrasah Aliyah units (1 state and

5 individual). The level of the density distribution of the household affects the density of population settlements. Based on the total population of the city of population densities varying.

Lhokseumawe included in the classification of urban areas while the population in 2010 was 171,163 people. The housing development is directed to the suburbs, namely areas that still have a lot of vacant lands and are unproductive land. In the center of the city, it is no longer possible to develop residential areas because of the limited land because it has high population density and dense settlements, and the downtown area has been widely used for the construction of public service facilities and the central government of Lhokseumawe City. The figure (Fig. 5) shows the occurrence of earthquakes that were recorded from 1910 to 2017 in the city of Lhokseumawe.

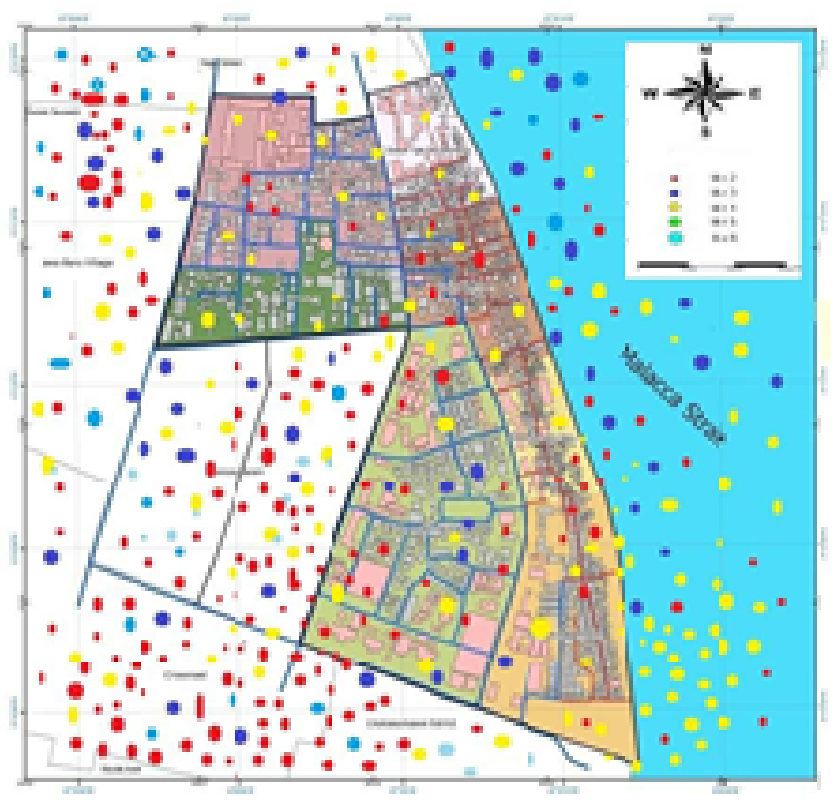

Fig. 5. Earthquake events along with magnitude values from 1910 to 2017 in the Lhokseumawe city area.

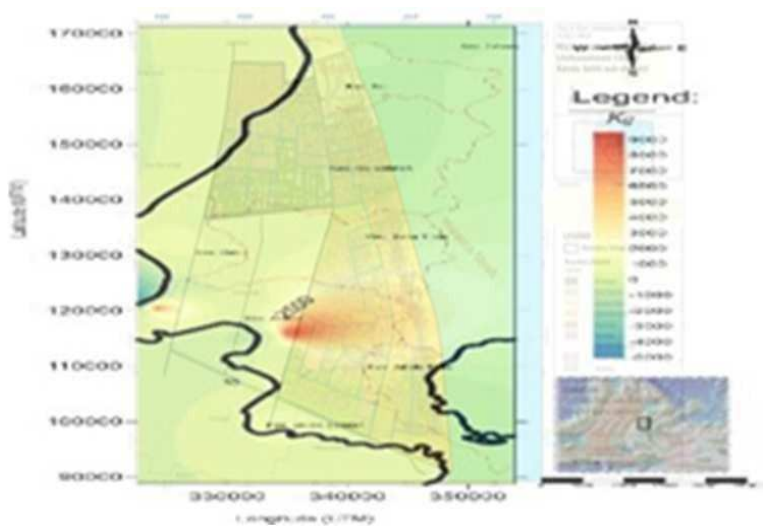

Fig 6. Micro zonation of vulnerability seismic index at Lhokseumawe area

\section{CONCLUSION}

The results obtained from this study are the seismic susceptibility $\mathrm{cm} / \mathrm{s} 2$. This is closely related to the total amount of damage to buildings in Lhokseumawe City due to the 2004 earthquake. The results of this study are the existence of areas that are very susceptible to seismic, namely Ujong Blang and Banda Sakti villages with seismic vulnerability index values $(\mathrm{Kg})$ ranging from $0 \mathrm{~cm} / \mathrm{s}^{2}$ $30542.32 \mathrm{~cm} / \mathrm{s}^{2}$. The highest value is located at Ujong Blang villages, which is $10397.1 \mathrm{~cm} / \mathrm{s}^{2}$. This is closely related to the total amount of damage to buildings in Lhokseumawe City due to the 2004 earthquake. The results 
of the seismic susceptibility index $(\mathrm{Kg})$ micro zonation in the Lhokseumawe District are shown in Fig.6.

\section{REFERENCES}

[1] N. Haerudin, R. Rustadi, H. Fitriawan, D. Siska, and M. Farid, "Earthquake Disaster Mitigation Mapping by Modeling of Land Layer and Site Effect Zone in The Kota Baru of South Lampung," J. Ilm. Pendidik. Fis. Al-BiRuNi, vol. 8, no. 1, pp. 53-61, 2019.

[2] E. Caffagni, D. W. Eaton, J. P. Jones, and M. van der Baan, "Detection and analysis of microseismic events using a Matched Filtering Algorithm (MFA)," Geophys. J. Int., p. ggw168 May 2016.

[3] Government of the Republic of Indonesia, "Law of the Republic of Indonesia Number 17 of 2017 on Long Term National Development Plan of 2005-2025," no. 17, 2007.

[4] P. Akademisi, P. Gedung, T. Gempa, P. Hazard, R. Gempa, and S. Perencanaan, "Cakupan:- Alasan Mengapa Perlu Melakukan Revisi Peta Gempa • Kondisi Tektonik dan Kegempaan Indonesia," 2013.

[5] I. Towhata, Springer Series in Geomechanics and Geoengineering: Geotechnical Earthquake Engineering. 2008.

[6] Nakamura, "Microsoft Word - 14WCEE YN HV," pp. 1-10, 2008.

[7] L. Gualtieri et al., "Modelling secondary microseismic noise by normal mode summation," Geophys. J. Int., vol. 193, no. 3, pp. 1732-1745, Jun. 2013.

[8] H. Chen, "Development status of microseismic monitoring technology in China," IOSR J. Eng., vol. 4, no. 1, pp. 16-19, 2014.

[9] F. Aminzadeh, T. A. Tafti, and D. Maity, "An integrated methodology for sub-surface fracture characterization using microseismic data: A case study at the NW Geysers," Comput. Geosci., vol. 54, pp. 39-49, Apr. 2013.
[10] N. Sugianto, M. Farid, and W. Suryanto, "Local geology condition of Bengkulu city based on seismic vulnerability index (Kg)," ARPN J. Eng. Appl. Sci., vol. 11, no. 7, pp. 4797-4803, 2016.

[11] A. Susilo and S. H. Wiyono, "Frequency Analysis and Seismic Vulnerability Index by Using Nakamura Methods at a New Artery Way in Porong,Sidoarjo, Indonesia," Int. J. Appl. Phys. Math., vol. 2, no. 4, pp. 227-230, 2013

[12] I. Kassaras, N. Voulgaris, and K. Makropoulos, "Determination of Site Response in Lefkada Town (W. Greece) by Ambient Vibration Measurements," no. September, pp. 7-12, 2008.

[13] M. Pando, L. Cano, L. E. Suárez, R. Ritta, and L. A. Montejo, "Weak-Motion Earthquakes and Micro tremors," 2008.

[14] M. Rodríguez, F. Chávez-García, and W. Stephenson, "Site Effects in An Alluvial Valley: A Comparison of Estimates from Earthquake and Microtremor Records," Proc. 12th World Conf. Earthq. Eng. Auckland, New Zeal., vol. Paper No., pp. 1-8, 2000.

[15] P. Bard, "European Commission - Research General Directorate Site EffectS assessment using AMbient Excitations Sixth progress report," October, pp. 1-20, 2004.

[16] A. L. Stork, J. P. Verdon, and J.-M. Kendall, "The microseismic response at the In Salah Carbon Capture and Storage (CCS) site," Int. J. Greenh. Gas Control, vol. 32, pp. 159-171, Jan. 2015.

[17] J. I. Sabbione and D. R. Velis, "A robust method for microseismic event detection based on automatic phase pickers," J. Appl. Geophys., vol. 99, pp. 42-50, Dec. 2013.

[18] X. L. Wang, F. W. Zwiers, V. R. Swail, and Y. Feng, "Trends and variability of storminess in the Northeast Atlantic region, 18742007," Clim. Dyn., vol. 33, no. 7-8, pp. 1179-1195, 2009. 